\title{
PERAN PROFITABILITAS DALAM MEMODERASI INVESTASI, LEVERAGE DAN KEBIJAKAN DIVIDEN TERHADAP NILAI PERUSAHAAN
}

\author{
Andi Prayitno ${ }^{1}$, Naz'aina $^{2 *}$, Sapna Biby ${ }^{3}$ \\ Pascasarjana Ilmu Manajemen Universitas Malikussaleh Lhokseumawe \\ Email: andiprayitno75@gmail.com,nazaina@unimal.ac.id,bby_sapna@yahoo.co.id)
}

\begin{abstract}
This study aimed to examin the effect of investment, leverage and dividend policy on firm value with profitability as a moderator in Non-Financial Services Companies in Indonesia during the 2014-2018 period. The number of samples in this study were 20 Non-Financial Services Companies that Paid dividend regularly during 2014-2018. The type of data was secondary data in the form of panel data obtained from the company's Annual Report. Data analysis method was Panel Data Regression. The results of this study found that leverage and profitability had a positive effect on firm value, where investment and dividend policy did not effect significantly on firm value, and profitability was able to moderate the effect of leverage on firm value, but was unable to moderate the effect of investment and dividend policy on firm value
\end{abstract}

Keywords: investment, leverage, dividend policy, profitability and firm value

\section{PENDAHULUAN}

Nilai perusahaan merupakan aspek yang sangat penting karena dapat mencerminkan kinerja perusahaan sehingga mempengaruhi persepsi investor terhadap perusahaan. Halimah \& Komariah (2017) mengatakan bahwa nilai perusahaan menjadi indikator yang tepat untuk melihat seberapa besar kekayaan pemegang saham dalam perusahaan tersebut. Nilai perusahaan yang tinggi menggambarkan bahwa kinerja perusahaan dalam keadaan baik sehingga dapat meyakinkan investor akan baiknya prospek perusahaan dimasa mendatang.

Investor akan mempercayai kinerja dan fundamental perusahaan pada saat nilai perusahaan tinggi (Anton, 2016). Ketika nilai perusahaan tinggi, berarti harga saham perusahaan mampu merefleksikan keadaan nyata mengenai kinerja perusahaan (Nam \& Uchida, 2019).

Nilai perusahaan dapat diketahui dengan beberapa rasio, seperti rasio PBV, PER, Return saham, MBVA dan Tobins Q(Anto, 2016; Apsari et al., 2015; Cahyono, 2016; Dewi \& Suaryana, 2013; Darmawati et al., 2018). Akan tetapi, penelitian ini menggunakan rasio Tobins Q, Tobins Q merupakan ukuran atas kepercayaan investor terhadap harga pasar saham perusahaan dan juga mempertimbangkan aset dan hutang perusahaan (Pratama \& Wiksuana, 2016). Oleh karena itu, Tobins Q menjadi rasio yang dapat mengukur seberapa besar investor yakin dan percaya akan harga pasar saham suatu perusahaan.

Riset sebelumnya juga menemukan bahwa nilai Tobins Q di Indonesia untuk periode selama periode 2002-2010 sebesar 1,30 dan menurun menjadi 1,01 untuk periode 2003-2013 (Darmawati et al., 2018). Nilai tersebut tergolong dalam kondisi yang baik dikarenakan berada di atas angka 1. Sementara itu, sektor jasa merupakan salah satu sektor pada perusahaan yang bergerak di Indonesia. Beberapa studi sebelumnya menunjukkan bahwa perusahaan jasa memiliki nilai Tobins Q sebesar 1,09 untuk periode 2008-2013 (Ihsan \& Sanjani, 2015). Nilai tersebut lebih tinggi dibandingkan dengan temuan Tobins Q pada sektor manufaktur yang hanya sebesar 0,92 untuk periode 2007-2015 (Indrawan, 2015). Hal ini menunjukkan bahwa sektor jasa manjadi sektor yang memiliki nilai perusahaan yang lebih unggul, sehingga perlu dilihat faktor-faktor apa saja yang mempengaruhinya.

Beberapa riset sebelumnya menemukan bahwa faktor yang mempengaruh nilai perusahaan adalah investasi, leverage, kebijakan dividen dan profitabilitas (Sudiyatno \& Puspitasari, 2010; Ihsan dan Sanjani, 2015; Anton, 2016; Darmawati et al., 2018), Akan 
tetapi, terdapat beberapa hasil riset yang menemukan bahwa investasi, leverage dividen serta profitabilitas tidak berpengaruh terhadap nilai perusahaan (Ruzita et al., 2010; Tarima et al., 2015; Setiadi, 2017). Berdasarkan research gap tersebut, terlihat bahwa masih terjadi perdebatan mengenai pengaruh investasi, leverage, kebijakan dividen dan profitabilitas terhadap nilai perusahaan dari waktu ke waktu, sehingga membuat penulis tertarik untuk mengkaji ulang variabel-variabel tersebut.

Selanjutnya, beberapa riset lainnya hanya menempatkan profitabilitas sebagai prediktor saja (Ruzita et al., 2010; Tarima et al., 2015; Bambang et al., 2012; Patricia et al., 2018; Le, 2019). Tetapi, penelitian ini mencoba menguji peranan profitabilitas dalam memoderasi pengaruh komponen keputusan keuangan terhadap nilai perusahaan. Profitabilitas yang tinggi mengindikasikan bahwa perusahaan memiliki laba yang tinggi sehingga mendorong manajer untuk mengembangkan perusahaan dengan berinvestasi (Manoppo et al., 2017). Manajer menjadi optimal dalam menentukan pendanaan eksternal dalam pertimbangan yang baik (Ali, 2009). Manajer akan mempertimbangkan untuk menggunakan dana internal dikarenakan kepemilikan sahamnya pada perusahaan yang tinggi (Indrawan, 2016). Hal ini menunjukkan bahwa profitabilitas mampu memoderasi pengaruh investasi, leverage dan kebijakan dividen terhadap nilai perusahaan (Ihsan dan Sanjani, 2015; Setiadi, 2017).

\section{METODE PENELITIAN}

Penelitian ini dilakukan untuk menganalisis peran profitabilitas dalam memoderasi investasi, leverage, kebijakan dividen terhadap nilai perusahaan jasa yang terdaftar di Bursa Efek Indonesia (BEI) selama periode 2014-2018. Data yang dikumpulkan adalah data sekunder yang diperoleh dari laporan keuangan perusahaan dengan mengakses situs resminya yaitu www.idx.co.id. Data dianalisis dengan menggunakan regresi data panel dengan menggunakan program EVIEWS.

Penarikan sampel menggunakan tehnik purposive sampling, yaitu menjadikan pandangan peneliti sebagai dasar dalam memilih perusahaan jasa yang akan diambil dengan menggunakan kriteria-kriteria tertentu (Sekaran \& Bougie, 2013). Adapun kriteria yang dijadikan acuan sebagai sampel yaituperusahaan jasa non keuangan yang memberikan deviden secara regular selama tahun 2014 - 2018 yang berjumlah 20 perusahaan.

Variabel dependen yaitu nilai perusahaan diproksikan dengan Tobins Q. Tobins Q dihitung dengan mencari kapitalisasi pasar dikurangi dengan total hutang dan dibagi dengan total aset (Ruzita et al., 2010; Darmawati et al., 2018). Investasi diukur dengan rasio pertumbuhan total aset yang dihitung dengan nilai Logaritma Natural dari perbandingan total aset periode saat ini dengan total aset periode sebelumnya (Ruzita et al., 2010; Darmawati et al., 2018). Leverage dihitung dengan membandingkan total hutang dengan total aset disebut dengan Debt to Asset Ratio (DAR) (Ruzita et al., 2010; Darmawati et al., 2018). Dividen menggunakan Dividend Payout Ratio (DPR) dihitung dengan membandingkan dividen per lembar saham terhadap laba per lembar saham (Roy, 2015; Natalia \& Kusumastuti, 2017). Profitabilitas dihitung dengan perbandingan laba bersih terhadap total aset yang disebut dengan Return on Asset (ROA) (Zeitun dan Saleh, 2015; Darmawati et al., 2018).

Model yang dapat dibangun untuk pengaruh antar variabel adalah sebagai berikut: Tobins_Q $\mathrm{Q}_{\mathrm{it}}=\beta_{0}+\beta_{1} \mathrm{INV}_{\mathrm{it}}+\beta_{2} \mathrm{DAR}_{\mathrm{it}}+\beta_{3} \mathrm{DPR}_{\mathrm{it}}+\beta_{4} \mathrm{ROA}_{\mathrm{it}}+\mathrm{e}_{\mathrm{it}}$ 
Tobins_Q $\mathrm{Q}_{\mathrm{it}}=\beta_{0}+\beta_{1} \mathrm{INV}_{\mathrm{it}}+\beta_{2} \mathrm{DAR}_{\mathrm{it}}+\beta_{3} \mathrm{DPR}_{\mathrm{it}}+\beta_{4} \mathrm{ROA}_{\mathrm{it}}+\beta 4(\mathrm{INV} * \mathrm{ROA})_{\mathrm{it}}+$ $\beta 4(\mathrm{DAR} * \mathrm{ROA})_{i t}+\beta 4(\mathrm{DPR} * \mathrm{ROA})_{i t}+\mathrm{e}_{\mathrm{it}}$

\section{HASIL DAN PEMBAHASAN}

\section{Analisis Deskriptif Statistik}

Pada analisis statistik deskriptif, akan terlihat bagaimana nilai rata-rata, nilai standar deviasi, nilai maksimum dan nilai minimum dari data yang digunakan dalam penelitian ini. Adapun hasil analisis deskriptif dalam penelitian ini adalah sebagai berikut:

Tabel 2

Analisis Deskriptif Statistik

\begin{tabular}{lccccc}
\hline & Mean & SD & Max & Min & Obs \\
\hline Tobins Q & 1.3782 & 0.6769 & 5.8212 & 0.4944 & 100 \\
INV & 0.1767 & 0.2520 & 1.2490 & -0.9318 & 100 \\
DAR & 0.5534 & 0.2068 & 1.7449 & 0.0749 & 100 \\
DPR & 0.6575 & 2.4764 & 23.3114 & 0.0127 & 100 \\
ROA & 0.0656 & 0.0520 & 0.2579 & 0.0023 & 100 \\
\hline Sumber & : Data Diolah, 2019 & & &
\end{tabular}

Berdasarkan Tabel 2 di atas, terlihat bahwa nilai rata-rata Tobins Q sebesar 1.3782 dengan standar deviasinya sebesar 0.6769 , dimana nilai rata-rata lebih besar dibandingkan dengan nilai standar deviasinya, yang menunjukkan bahwa Tobins $Q$ dalam penelitian ini memiliki fluktuasi yang kecil. Nilai tertinggi Tobins Q sebesar 5.8212 dan nilai terendahnya sebesar 0.4944 dengan banyaknya observasi yaitu 100 observasi.

Selanjutnya, investasi memiliki nilai rata-rata sebesar 0.1767 dengan nilai standar deviasnya sebesar 0.2520 . Hasil tersebut menunjukkan bahwa nilai rata-rata lebih kecil dibandingkan nilai standar deviasinya yang artinya fluktuasi data investasi dalam penelitian ini tergolong fluktuasi yang tinggi. Adapun nilai investasi tertinggi dalam penelitian ini sebesar 1.2490 dan nilai terendahnya sebesar -0.9318 dengan total observasi sebanyak 100 observasi.

Selanjutnya, DAR memiliki nilai rata-rata sebesar 0.5534 dengan standar deviasi sebesar 0.2068, dimana nilai rata-rata berada di atas nilai standar deviasi, yang menunjukkan bahwa fluktuasi DAR dalam penelitian ini tergolong dalam fluktuasi yang tinggi. Sementara itu, nilai tertinggi DAR adalah 1.7449 , sedangkan nilai terendahnya sebesar 0.0749 . Banyaknya observasi yang dilakukan adalah 100 observasi.

DPR dalam penelitian ini memiliki nilai rata-rata sebesar 0.6575 dengan nilai standar deviasinya sebesar 2.4764 , dimana nilai rata-rata berada di atas nilai standar deviasi yang menunjukkan bahwa DPR dalam penelitian ini memiliki fluktuasi yang cukup tinggi. Sementara itu, nilai tertinggi DPR mencapai angka 23.3114 dan nilai terendahnya sebesar 0.0127 yang dilakukan terhadap 100 observasi.

Terakhir, nilai rata-rata ROA sebesar 0.0656 dengan standar deviasi sebesar 0.0520 . Hasil tersebut menunjukkan bahwa ROA memiliki nilai rata-rata yang lebih tinggi dari pada nilai standar deviasi, artinya

ROA dalam penelitian ini memiliki fluktuasi yang kecil. Sementara itu, nilai tertinggi untuk ROA adalah 0.2579 dan nilai terendahnya sebesar 0.0023 serta banyaknya observasi yaitu 100 observasi.

\section{Analisis Korelasi}


Analisis korelasi merupakan tahapan pengujian untuk melihat hubungan (korelasi) dari setiap variabel yang digunakan dalam penelitian ini. Adapun hasil analisis korelasi dalam penelitian ini dapat dilihat sebagai berikut:

Tabel 3

Analisis Korelasi

\begin{tabular}{|c|c|c|c|c|c|}
\hline & TOBINS_Q & INV & DAR & DPR & ROA \\
\hline \multirow{2}{*}{ TOBINS_Q } & 1.0000 & & & & \\
\hline & ---- & & & & \\
\hline \multirow{2}{*}{ INV } & -0.1846 & 1.0000 & & & \\
\hline & $-1.8600 *$ & ----- & & & \\
\hline \multirow{2}{*}{ DAR } & 0.4636 & -0.0851 & 1.0000 & & \\
\hline & $5.1809^{* * * *}$ & -0.8461 & ----- & & \\
\hline \multirow{2}{*}{ DPR } & -0.0806 & -0.0845 & -0.0720 & 1.0000 & \\
\hline & -0.8014 & -0.8404 & -0.7154 & ----- & \\
\hline \multirow{2}{*}{ ROA } & 0.6754 & -0.2171 & -0.0362 & -0.1246 & 1.0000 \\
\hline & 9.0676 *** & $-2.2020 * *$ & -0.3586 & -1.2435 & ---- \\
\hline ber & Data & Diolah, 20 & & & \\
\hline
\end{tabular}

Berdasarkan hasil analisis korelasi yang disajikan pada Tabel 5.2, ditemukan bahwa investasi memiliki hubungan negatif dengan Tobins Q sebesar -0.1846 dan signifikan pada level $10 \%$. Berbeda dengan DAR dan ROA yang memiliki hubungan positif dengan Tobins Q masingmasing sebesar 0.4636 dan 0.6754 , dimana bentuk hubungan tersebut signifikan pada level 1\%. Adapun DPR memiliki hubungan negatif dengan Tobins Q sebesar 0.0806 tetapi tidak signifikan.

Selanjunya, untuk hubungan antar variabel besar, DAR dan DPR memiliki hubungan negatif dengan investasi masing-masing sebesar -0.0851 dan -0.0845 tetapi tidak signifikan. Akan tetapi ROA dengan Investasi memiliki hubungan negatif dan signifikan pada level 5\% sebesar -0.2171 .

DPR dan ROA memiliki hubungan negatif dengan DAR masing-masing sebesar -0.0720 dan -0.0362 tetapi tidak signifikan, dan ROA memiliki hubungan negatif dengan DPR sebesar 0.1246 tetapi tidak signifikan.

\section{Hasil Pemilihan Model Regresi Data Panel}

Hasil Uji Chow dan Uji Hausman dalam penelitian ini untuk kedua model regresi yang digunakan dapat dilihat pada tabel di bawah ini.

\begin{tabular}{lcc} 
& \multicolumn{2}{c}{ Tabel 4 } \\
\hline & $\begin{array}{c}\text { Direct Model } \\
(\text { Prob })\end{array}$ & $\begin{array}{c}\text { Interaction } \\
\text { Model }\end{array}$ \\
\hline Chow Test & 0.0001 & 0.0000 \\
Hausman Test & 0.9857 & 0.3893 \\
\hline Sumber : & Data Diolah, 2019 &
\end{tabular}

Hasil pemilihan model menunjukkan bahwa uji chow dan uji hausman, maka model yang tepat digunakan dalam penelitian ini adalah random effect model.

\section{ESTIMASI REGRESI DAN PENGUJIAN HIPOTESIS}


Tabel 5

Fixed Effect Model

\begin{tabular}{|c|c|c|c|c|}
\hline \multirow{2}{*}{ Variable } & \multicolumn{2}{|c|}{ Direct Model } & \multicolumn{2}{|c|}{ Interaction Model } \\
\hline & Koef & $t_{\text {hitung }}$ & Koef & $t_{\text {hitung }}$ \\
\hline $\mathrm{C}$ & -0.1368 & -0.8836 & 0.5975 & $2.3882 * *$ \\
\hline INV & -0.0036 & -0.0242 & -0.0390 & -0.1292 \\
\hline DAR & 1.6433 & $7.1028 * * *$ & 0.4912 & 1.2431 \\
\hline DPR & 0.0122 & 0.8494 & -0.0001 & -0.0017 \\
\hline ROA & 9.1059 & $10.2444 * * *$ & 0.7368 & 0.2649 \\
\hline INV*ROA & & & 5.0165 & 1.2576 \\
\hline $\mathrm{DAR} * \mathrm{ROA}$ & & & 11.42201 & $3.1472 * * *$ \\
\hline $\mathrm{DPR} * \mathrm{ROA}$ & & & 0.4556 & 1.0245 \\
\hline R-squared & & 0.6902 & & 0.7300 \\
\hline Adj R-squared & & 0.6772 & & 0.7095 \\
\hline F-statistic & & $52.9307 * * *$ & & $35.5477 * * *$ \\
\hline Durbin-Watsol & & 1.1544 & & 1.0484 \\
\hline $\begin{array}{lc}\text { Sumber } & \vdots \\
\text { Keterangan } & \vdots\end{array}$ & $\begin{array}{l}\text { Data Diol } \\
* * *, * *, *\end{array}$ & ffik & & \\
\hline
\end{tabular}

Berdasarkan tabel di atas, maka persamaan regresi yang dapat dibangun adalah sebagai berikut:

Tobins_Q $=\quad-0.1368-0.0036 \mathrm{INV}+1.6433 \mathrm{DAR}+0.0122 \mathrm{DPR}+9.1059 \mathrm{ROA}$

Tobins_Q $=0.5975-0.0390 \mathrm{INV}+0.4912 \mathrm{DAR}-0.0001 \mathrm{DPR}+0.7368 \mathrm{ROA}+$ $5.0165(\mathrm{INV} * \mathrm{ROA})+11.42201(\mathrm{DAR} * \mathrm{ROA})+0.4556(\mathrm{DPR} * \mathrm{ROA})$

Berdasarkan perasamaan di atas, ditemukan bahwa pada Direct Model, investasi memiliki nilai koefisien negatif sebesar -0.0036 yang artinya ketika investasi naik $1 \%$ maka nilai perusahaan akan turun sebesar 0,0036 , tetapi nilai tersebut memiliki $t_{\text {hitung }}$ yangt idak signifikan secara statistik, sehingga $\mathrm{H}_{1}$ ditolak yang artinya investasi tidak berpengaruh signifikan terhadap nilai perusahaan jasa di Indonesia.

Selanjutnya, DAR memiliki nilai koefisien yang positif sebesar 1.6433, artinya ketika leverage naik $1 \%$, maka nilai perusahaan akan ikut naik sebesar 1.6433 . Adapun nilai $t_{\text {hitung }}$ yang diperoleh sebesar 7.1028 yang signifikan pada level $1 \%$, maka $\mathrm{H}_{2}$ diterima yang artinya levereage berpengaruh positif dan signifikan terhadap nilai perusahaan jasa di Indonesia.

Selanjutnya, DPR memiliki nilai koefisien positif sebesar 0.0122 , yang artinya ketika kebijakan dividen naik $1 \%$, maka nilai perusahaan akan bertambah sebesar 0.0122. Akan tetapi, nilai koefisien tersebut memiliki nilai $t_{\text {hitung }}(0.8494)$ yang tidak signifikan secara statistik, sehingga $\mathrm{H}_{3}$ ditolak yang artinya kebijakan dividen tidak berpengaruh signifikan terhadap nilai perusahaan jasa di Indonesia.

ROA memiliki nilai koefisein positif sebesar 9.1059 yang artinya ketika profitabilitas perusahaan naik $1 \%$ maka nilai perusahaan akan meningkat sebesar 9.1059. Nilai koefisien tersebut memiliki nilai $\mathrm{t}_{\text {hitung }}(10.2444)$ yang signifikan pada level $1 \%$, sehingga $\mathrm{H}_{4}$ diterima yang artinya profitabilitas berpengaruh positif dan signifikan terhadap nilai perusahaan jasa di Indonesia.

Untuk persamaan model interaksi, terlihat bahwa nilai koefisien pada INV*ROA sebesar 5.0165, artinya ketika ROA naik 1\%, maka hubungan investasi dengan nilai perusahaan akan menguat sebesar 5.0165. Akan tetapi, nilai tersebut memiliki nilai $t_{\text {hitung }}$ sebesar 1.2576 yang tidak signifikan secara statistik, maka $\mathrm{H}_{5}$ ditolak, yang artinya 
profitabilitas tidak mampu memoderasi pengaruh investasi terhadap nilai perusahaan jasa di Indonesia.

Selanjutnya, nilai koefisien dari DAR*ROA sebesar 11.42201, artinya ketika profitabilitas naik 1\%, maka hubungan leverage dengan nilai perusahaan menguat sebesar 11.42201. Nilai koefisien tersebut memiliki nilai $t_{\text {hitung }}$ sebesar 3.1472 dan tergolong signifikan pada level $1 \%$, maka $\mathrm{H}_{6}$ diterima yang artinya profitabilitas memoderasi pengaruh leverage terhadap nilai perusahaan jasa di Indonesia.

Adapun nilai koefisien untuk DPR*ROA sebesar 0.4556, artinya jika profitabilitas naik $1 \%$, maka hubungan kebijakan dividen dengan nilai perusahaan akan menguat sebesar 0.4556. Akan tetapi, nilai koefisien tersebut tidak signifikan secara statistik. Maka dari itu, $\mathrm{H}_{7}$ dalam penelitian ini ditolak, artinya profitabilitas tidak memoderasi pengaruh kebijakan dividen terhadap nilai perusahaan jasa di Indonesia.

\section{Pembahasan}

\section{Pengaruh Investasi terhadap Nilai Perusahaan}

Berdasarkan hasil analisis data yang telah dilakukan, ditemukan bahwa investasi tidak berpengaruh signifikan terhadap nilai perusahaan jasa di Indonesia. Hal ini sejalan dengan hasil penelitian Ruzita et al., (2010) dan Tarima et al., (2016) yang menemukan bahwa investasi tidak berpengaruh signifikan terhadap nilai perusahaan. Hasil ini menunjukkan bahwa investasi bukanlah menjadi prediktor dalam meningkatkan nilai perusahaan jasa di Indonesia.

Hasil penelitian ini menunjukkan bahwa nilai perusahaan tetap meningkat meskipun kebijakan investasi perusahaan buruk. Investasi memberikan pengaruh yang tidak signifikan terhadap nilai pasar dikarenakan penerapan investasi yang optimal tidak menjadi pertimbangan investor dalam menilai saham perusahaan (Ruzita et al., 2010). Investor akan memperhatikan tingkat fluktuatif saham yang menyebabkan nilai pasar perusahaan menjadi meningkat, bukan dikarenakan kebijakan investasi yang dilakukan oleh manager perusahaan dikarenakan hal tersebut tergolong dalam private information (Tarima et al., 2016).

\section{Pengaruh Leverage terhadap Nilai Perusahaan}

Hasil penelitian ini menemukan bahwa leverage berpengaruh positif dan signifikan terhadap nilai perusahaan. Hasil ini mengindikasikan bahwa tingginya leverage membuat nilai perusahaan meningkat. Hal ini sejalan dengan temuan Darmawati et al. (2018) serta Muharti \& Anita (2017) yang menemukan bahwa leverage berpengaruh positif dan signifikan terhadap nilai perusahaan.

Hasil penelitian ini juga sejalan dengan MM dengan pajak (Modigliani dan Miller, 1963) yang menyatakan bahwa struktur modal dapat mempengaruhi nilai perusahaan dengan berubahnya tingkat hutang yaitu keuntungan dari pajak. Perusahaan dengan leverage yang tinggi menunjukkan bahwa perusahaan tersebut merupakan perusahaan yang berpotensi dan perusahaan yang besar sehingga menarik investor dan nilai perusahaan meningkat (Fitriani, 2016).

\section{Pengaruh Kebijakan Dividen terhadap Nilai Perusahaan}

Hasil penelitian ini menemukan bahwa kebijakan dividen tidak berpengaruh signifikan terhadap nilai perusahaan jasa di Indonesia. Ini menunjukkan bahwa kebijakan dividen tidak menjadi prediktor dalam meningkatkan nilai perusahaan jasa di Indonesia. Hasil ini juga sejalan dengan penelitian yang dilakukan oleh Setiadi (2017); Cahyono (2016) serta Tahu \& 
Susilo (2017) yang menemukan bahwa kebijakan dividen tidak berpengaruh signifikan terhadap nilai perusahaan.

Hasil penelitian ini juga mendukung irrelevant dividend theory yang mengatakan bahwa dividen tidak bisa dijadikan indikator yang relevan dalam melihat nilai perusahaan (Modigliani \& Miller 1961). Investor juga lebih menyukai capital gain dibandingkan dengan dividen tunai, sehingga tidak berdampak terhadap nilai perusahaan (Litzenberger \& Ramaswamy, 1979). Black \& Scholes (1974) juga berpendapat bahwa tidak semua investor menyukai pembayaran dividen tunai, terkhusus bagi investor yang hanya mengharapkan sahamnya sebagai penghasilan maka lebih mengutamakan capital gain dibanding dengan dividen tunai.

\section{Pengaruh Profitabilitas terhadap Nilai Perusahaan}

Hasil penelitian ini menemukan bahwa profitabilitas memiliki pengaruh positif dan signifikan terhadap nilai perusahaan jasa di Indonesia. Ini menjukkan bahwa kenaikan profitabilitas akan memberikan dampak positif terhadap nilai perusahaan. Hal ini juga membuktikan bahwa profitabilitas merupakan prediktor nilai perusahaan jasa di Indonesia. Hasil ini sejalan dengan temuan Patricia et al., (2018) dan Le (2019) yang menemukan bahwa profitabilitas berpengaruh positif terhadap nilai perusahaan.

Hasil penelitian ini sejalan dengan Signalling Theory yang menyatakan bahwa laba menjadi informasi yang dapat memancarkan sinyal positif ke pasar sehingga nilai perusahaan meningkat (Ross, 1977). Perusahaan dengan laba yang tinggi menjadi perusahaan yang menarik investor, dan nilai perusahaan meningkat. Darmawati et al. (2018) juga berpendapat bahwa profitabilitas dapat dijadikan kinerja buku atau kinerja akuntansi perusahaan, sehingga kinerja yang baik akan memberikan sinyal positif dan menaikkan nilai perusahaan.

\section{Peran Profitabilitas dalam Memoderasi Pengaruh Investasi terhadap Nilai Perusahaan}

Hasil penelitian ini menemukan bahwa profitabilitas tidak memoderasi pengaruh investasi terhadap nilai perusahaan jasa di Indonesia. Hasil ini menunjukkan bahwa pengaruh investasi terhadap nilai perusahaan tidak tergantung pada tingkat profitabilitas perusahaan. Hasil penelitian ini sejalan dengan kajian yang pernah dilakukan oleh Muchlis (2013) dan Husain (2014) yang menemukan bahwa profitabilitas tidak menjadi moderator pada pengaruh investasi terhadap nilai perusahaan.

Hasil penelitian ini menunjukkan bahwa keputusan investasi perusahaan tidak bergantung pada tingkat laba perusahaan dalam meningkatkan nilai perusahaan. Jensen (1986) berpendapat bahwa manajer menggunakan free cash flow perusahaan dimana investasi yang berlebihan berpengaruh negatif terhadap nilai perusahaan. Investasi tetap dijalankan untuk ekspansi perusahaan ketika arus kas bebas perusahaan tinggi, meskipun pada saat itu perusahaan tidak memiliki keuntungan yang tinggi.

\section{Peran Profitabilitas dalam Memoderasi Pengaruh Leverage terhadap Nilai Perusahaan}

Hasil analisis statistik yang telah dilakukan menunjukkan bahwa profitabilitas mampu memoderasi pengaruh Leverage terhadap nilai perusahaan jasa di Indonesia, dimana pengaruh leverage terhadap nilai perusahaan tergantung pada tingkat profitabilitas perusahaan. Selanjutnya, efek moderasi yang diberikan adalah positif, artinya profitabilitas memperkuat pengaruh leverage terhadap nilai perusahaan. Hasil ini sejalan dengan temuan Setiadi (2017) yang menemukan bahwa profitabilitas mampu memoderasi pengaruh leverage terhadap nilai perusahaan. 
Hasil penelitian ini menunjukkan bahwa tingkat laba menjadi peran yang dapat meningkatkan hubungan kebijakan pendanaan dengan nilai perusahaan. Perusahaan dengan profitabilitas yang tinggi akan memperoleh dana internal yang tinggi, sehingga kebijakan pendanaan dari eksternal akan berkurang dan nilai perusahaan akan meningkat. Donaldson (1961) juga berpendapat bahwa sebaiknya perusahaan mengutamakan penggunaan dana-dana internal dari pada dana eksternal dalam menjalankan perusahaan.

\section{Peran Profitabilitas dalam Memoderasi Pengaruh Leverage terhadap Nilai Perusahaan}

Hasil penelitian ini menunjukkan bahwa profitabilitas tidak mampu memoderasi pengaruh kebijakan dividen terhadap nilai perusahaan jasa di Indonesia. Hal ini mengindikasikan bahwa pengaruh kebijakan dividen terhadap nilai perusahaan tidak tergantung pada tingkat profitabilitas perusahaan. Hasil penelitian ini sejalan dengan temuan Setiadi (2017) yang menemukan bahwa profitabilitas tidak memoderasi pengaruh kebijakan dividen terhadap nilai perusahaan.

Hasil penelitian ini menunjukkan bahwa tingkat kemampuan menghasilkan laba tidak menjadi indikator dalam meningkatkan hubungan kebijakan dividen dengan nilai perusahaan. Miller \& Modigliani (1961) berpendapat bahwa kebijakan dividen bukanlah ukuran relevan dalam melihat nilai perusahaan. Tak jarang perusahaan memberikan dividen hanya untuk menarik perhatian pasar, meskipun pada saat itu perusahaan memiliki kinerja yang tidak terlalu baik. Hal ini menunjukkan bahwa profitabilitas tidak menjadi faktor penguat pengaruh dividen terhadap nilai perusahaan.

\section{KESIMPULAN}

Berdasarkan hasil penelitian yang telah dilakukan, maka kesimpulan penelitian ini yaitu investasi dan kebijakan deviden tidak berpengaruh signifikan terhadap nilai perusahaan. Leverage dan profitabilitas berpengaruh positif dan signifikan terhadap nilai perusahaan. Sementara itu profitabilitas tidak memoderasi pengaruh investasi dan kebijakan deviden terhadap nilai. Namun profitabilitas memoderasi pengaruh leverage terhadap nilai perusahaan.

\section{SARAN}

1. Investasi tidak berpengaruh signifikan terhada nilai perusahaan, sehingga disarankan kepada manajer untuk tidak khawatir dalam menerapkan keputusan investasi pada proyek-proyek potensial.

2. Leverage berpengaruh positif terhadap nilai perusahaan, sehingga disarankan pada pemegang kepentingan perusahaan untuk menggunakan dana eksternal karena dapat memberikan keuntungan bagi perusahaan.

3. Disarankan kepada para investor untuk tidak memperhatikan Dividend Payout Ratio perusahaan karena hal tersebut tidak relevan dalam menjelaskan kinerja pasar perusahaan.

4. Disarankan kepada pihak pemegang kepentingan untuk menerapkan manajemen laba yang baik karena berdampak pada nilai pasar perusahaan.

5. Kepada peneliti lainnya untuk menambah variable lain seperti kepemilikan saham, Coorporate Governance dan biaya keagen yang dapat mempengaruhi nilai perusahaan dengan proksi dan model ekonometrika yang berbeda untuk pengembangan keilmuan di bidang keuangan perusahaan.

\section{DAFTAR PUSTAKA}

Anton, Sorin. (2016). The Impact of Dividend Policy on Firm Value. A Panel Data Analysis of Romanian Listed Firms. Journal of Public Administration, Finance and Law. 1(1). 
Apsari, Idha., Ayu Dwiatmanto dan Devi Farah Azizah. (2015). Pengaruh Return On Equity, Net Profit Margin, Debt To Equity Ratio dan Longterm Debt To Equity Ratio Terhadap Price Book Value. Jurnal Administrasi Bisnis (JAB). Vol 27. No 2.

Bambang, S., Puspitasari, E., \& Kartika, A. (2012). The company's policy, firm performance, and firm Value: An empirical research on Indonesia Stock Exchange. American International Journal of Contemporary Research, 2(12), 30-40.

Black , Fischer \& Myron Scholes. (1974). The Effects of Dividend Yield and Dividend Policy on Common Stock Prices and Returns. Journal of Financial Economics 1.

Cahyono, Heri Setiyo. (2016). Keputusan Investasi, Keputusan Pendanaan dan Kebijakan Dividen Sebagai Determinan Nilai Perusahaan. Akuisisi. Vol 12. No 2.

Charles, M., \& Arnold. (2012). Profitability, dividend and firm performance in Nigeria Stock Exchange. International Review of Business Research Papers. Vol 6. No 5.

Daniel. (2015). Pengaruh Faktor Internal Terhadap Harga Saham Pada Perusahaan LQ 45 yang Terdaftar di Bursa Efek Indonesia. Jurnal EMBA. Vol 3. No 3.

Darmawati., Fauziah Mat N., Wahyuddin Albra., Muhammad Arifai dan Anshari Saleh. (2010). Dynamic Performance of Indonesian Public Company: An Analysis of Financial Decision Behavior. Cogent Economics \& Finance. 1 (6)

Dewi, Luh Putu Utami dan I Wayan Wirasadena. (2018). Pengaruh Keputusan Investasi, Keputusan Pendanaan, Kebijakan Dividen dan Tingkat Inflasi Terhadap Nilai Perusahaan. E-Jurnal Akuntansi Universitas Udayana. Vol 23. No 2.

Dewi, Putu Dina Aristya dan I.G.N.A. Suaryana. (2013). Pengaruh EPS, DER dan PBV Terhadap Harga Saham. E-Jurnal Akuntansi Universitas Udayana. Vol 4. No 1.

Dimitri dan Sumani. (2013). Analisis Pengaruh Likuiditas, Profitabilitas, Ukuran, Usia dan Pertumbuhan Perusahaan Terhadap Struktur Modal. Jurnal Manajemen. Vol 1. No 1.

Donaldson, G. (1961). Corporate Debt Capacity: A Study of Corporate Debt Policy and The Determinants of Corporate Debt Capacity. Division of Research, Harvard Business School, Harvard University, Cambridge, MA.

Fama, Eugene F. \& Jensen, Michael C. (1983). Separation of Ownership and Control. Journal of Law and Economic. 26.

Fama, Eugene F., \& Miller, M. H. (1972). The Theory of Finance. New York, NY: Holt, Rinehart, and Winston.

Fahmi, Irham. (2012). Manajemen Investasi. Salemba Empat, Jakarta.

Fitriani, Ramadhani Srifitra. (2016). Pengaruh NPM, PBV dan DER Terhadap Harga Saham Pada Perusahaan Sub Sektor Makanan dan Minuman di Bursa Efek Indonesia. eJournal Administrasi Bisnis. Vol 4. No 3.

Ghozali, Imam. (2016). Aplikasi Analisis Multivariate dengan Program IBM SPSS 21. Edisi Kedelapan. Badan Penelitian UNDIP, Semarang.

Ginting, dan Suryani. (2013). Analisis Faktor Faktor yang Mempengaruhi Harga Saham pada Perusahaan Manufaktur di Bursa Efek Indonesia. Jurnal Wira Ekonomi Mikroskil. Vol 3. No 2 . 
Gordon and Litner, John. (1962a). Distribution of Incomes of Corporations Among Dividends, Retained Earnings and Taxes. The American Economic Review. Vol 46, 97-113.

Gujarati, Domador dan Dawn Porter. (2012). Dasar-Dasar Ekonometrika. Salemba Empat, Jakarta.

Hamidy, Rahman Rusdi., I Gusti Bagus Wiksuana dan Luh Gede Sri Artini. (2015). Pengaruh Struktur Modal Terhadap Nilai Perusahaan dengan Profitabilitas Sebagai Variabel Intervening Pada Perusahaan Properti dan Real Estate di Bursa Efek Indonesia. EJurnal Ekonomi dan Bisnis Universitas Udayana. Vol 4. No 10.

Himmelberg, Charles P., R. Glenn Hubbard and Darius Palia. (1999). Understanding The

Determinants Of Managerial Ownership And The Link Between Ownership And

Performance. Journal of Financial Economics 53, 353-384

Hudan, Yusron et al. (2016). Pengaruh Profitabilitas, Likuiditas, Dan Ukuran Perusahaan Terhadap Struktur Modal. e-Proceeding of Management. Vol.3. No.

Husna dan Afni (2015). Faktor-faktor yang Mempengaruhi Harga Saham. Jurnal EMBA. Vol 1. No 4 .

Husain. (2014). Pengaruh investasi terhadap nilai perusahaan dengan profitabilitas sebagai variabel moderasi. Jurnal akuntansi dan bisnis. Vol 2. No 1.

Indrawan. (2013) Pengaruh Investasi dan Leverage terhadap Nilai Perusahaan Perusahaan Manfuaktur di BEI dengan Profitabilitas sebagai Variabel Moderator. Jurnal Akuntansi Keuangan. Vol 1. No 5.

Ihsan, Juli \& Sanjani. (2015). Efek Moderasi Profitabilitas pada Pengaruh keputusan pendanaan dan kebijakan dividen terhadap Nilai Perusahaan Jasa di Indonesia. Jurnal EMBA. Vol 1. No 3.

Ismail, Anas et al. (2015). Faktor-Faktor yang Mempengaruhi Struktur Modal pada Perusahaan Property dan Real Estate. Jurnal Ekonomi Manajemen Sumber Daya. Vol 17. No 1 .

Jensen, M. C. (1986). Agency Costs Of Free Cash Flow, Corporate Finance, And Takeovers. The American Economic Review. 76 (2). 323-329.

Jogiyanto. (2009). Teori Portofolio dan Analisis Investasi. Edisi Ketiga. BPFE, Yogyakarta.

Kasmir. (2014). Analisis Laporan Keuangan. Rajawali Pers, Jakarta.

Kesuma Ali. (2009). Analisis Faktor yang Memperngaruhi Struktur Modal Serta Pengaruhnya terhadap Harga Saham Perusahaan Real Estate yang Go-Public di BEI. Jurnal Manajemen dan Kewirausahaan. Vol 2. No 1.

Kholis et al. (2014). Determinasi Harga Saham pada Sektor Pertanian di BEI. Jurnal Unund. Vol 1. No 3 .

Le, Ben. (2019). Working Capital Management and Firm's Valuation, Profitability and Risk: Evidence From A Developing Market. International Journal of Managerial Finance.

Litzenberger, R.H. \& K. Ramaswamy. (1979). The Effects of Personal Taxes and Dividends on Capital Asset Prices: Theory and Empirical

Evidence. Journal of Financial Economics. Vol 7. 163-195. 
Manoppo, I Gusti Made., Nyi Ruhyan Wani. (2017) Faktor-Faktor yang Mempengaruhi Harga Saham. Jurnal Unund. Vol 2. No 2.

Masril. (2014) Faktor-Faktor yang Mempengaruhi Harga Saham Sektor Keuangan di BEI. Jurnal Ekonomi dan Manajemen. Vol 1. No 4.

Modigliani, F. and Miller, M.H. (1958). The Cost of Capital, Corporate Finance, And The Theory of Investment. The American Economic Review. Vol. 48 No. 2.

Modigliani, F. and Miller, M.H. (1963). Corporate Income Taxes and The Cost of Capital: A Correction. The American Economic Review. Vol 53. No 2.

Moniaga, Fernandes. (2013). Struktur Modal, Profitabilitas dan Struktur Biaya Terhadap Nilai Perusahaan Industri Keramik, Porcelen dan Kaca Periode 2007-2011. Jurnal EMBA. Vol 1. No 4. Hal 433-442.

Muchlis. (2013). Pengaruh keputusan investasi dan keputusan pendanaan terhadap nilai perusahaan dengan profitabilitas sebagai variabel moderasi pada perusahaan sektor pertambangan yang terdaftar di BEI. Jurnal Emva. Vol 1. No 1.

Munawir. (2012). Analisis Laporan Keuangan. Rajawali Pers, Jakarta.

Muharti \& Anita. (2017). Pengaruh Keputusan Investasi, Pendanaan, Kebijakan Deviden Terhadap Nilai Perusahaan. Jurnal Ilmiah Ekonomi dan Bisnis. 13(2).

Nam, H., \& Uchida, K. (2019). Accounts payable and firm value: International evidence. Journal of Banking \& Finance, 102, 116-137.

Natalia, Ami \& Retno Kusumastuti. (2017). An Analysis of Agency Costs and Dividend Payout Ratio of Non-Financial Companies. MIMBAR. Vol 33. No 2.

Oktaviani, Riza Pramita dan Sasi Agustin. (2017). Pengaruh PER, EPS, DPR terhadap Harga Saham Pada Perusahaan Pertambangan. Jurnal Ilmu dan Riset Manajemen. Vol 6. No 2.

Pardiyanto. (2016). Pengaruh Struktur Modal, Profitabilitas, Ukuran Perusahaan dan Likuiditas Terhadap Nilai Perusahaan. Jurnal Administrasi Publik. Vol 1. No 2.

Patricia., Primsa Bangun \& Malem Ukur Tarigan. (2018). Pengaruh Profitabilitas,

Likuiditas,dan Ukuran Perusahaan Terhadap Nilai Perusahaan. Jurnal Manajemen Bisnis. 13(1).

Polii Setyawati, Nurjamin dan Khairanur. (2014). Determinasi Harga Saham pada Sektor Perbankan di Indonesia. Jurnal EMBA. Vol 3. No 4Sari, Yuni Indra dan Suhermin. (2016). Pengaruh Faktor-Faktor Fundamental Terhadap Harga Saham Pada Perusahaan Telekomunikasi. Jurnal Ilmu dan Riset Manajemen. Volume 5. Nomor 7.

Putri, Hanafiah PD dan Isynuwardhana. (2016). Pengaruh Keputusan Investasi, Keputusan Pendanaan Dan Kebijakan Dividen Terhadap Nilai Perusahaan (Studi Empiris Pada Sub Sektor Industri Barang Konsumsi Yang Terdaftar di Bursa Efek Indonesia Periode 2010-2013). Proceeding of Management : Vol.3, No.1 April 2016.

Ross, Stephen A. (1977). The Determination of Financial Structure: The Incentive-Signalling Approach. The Bell Journal of Economics. Vol. 8. No. 1.

Roy, Amitava. (2015). Dividend Policy, Ownership Structure, And Corporate Governance: An Empirical Analysis of Indian Firm. Indian Journal of Corporate Governance. $8(1)$. 
Ruzita Rahim, Mohd Yasimi Y., Norazlan and Fauziah Mat N. (2010). Investment, Board Governance and Firm Value: A Panel Data Analysis. International Review of Business Research Papers. Vol 6. No 5.

Sari, Oktavia Kartika dan Sapari. (2017). Pengaruh Pertumbuhan Penjualan, Earning Per Share, dan Kebijakan Dividen terhadap Harga Saham. Jurnal Ilmu dan Riset Akuntansi. Vol 6. No 8.

Setiadi. (2017). Peranan Profitabilitas dalam Memoderasi Pengaruh Keputusan Keuangan terhadap NIlai Perusahaan Publik di Indonesia. Jurnal Ekonometrika. Vol 2. No 1.

Setywawati. (2016) Pengaruh keputusan investasi dan keputusan pendanaan terhadap fluktuasi harga saham di Pasar Modal. Jurnal Ekonomi dan Bisnis. Vol 1. No 3.

Septia, Adi. (2015). Pengaruh Profitabilitas, Keputusan Investasi, Keputusan Pendanaan dan Kebijakan Dividen terhadap Nilai Perusahaan pada Perusahaan Manufaktur yang Terdaftar di BEI. Jurnal EMBA. Vol 1. No 3.

Siahaan, Dhani Beslyder. (2017). Pengaruh PBV, DER dan ROE Terhadap Harga Saham Perusahaan Manufaktur yang terdaftar di Bursa Efek Indonesia. eJournal Administrasi Bisnis. 5 (3).

Sugiyono. (2016). Metode Penelitian Kuantitatif, Kualitatif dan R\&D. Alfabeta, Bandung.

Suryadi, Hasdi. (2017). Analisis Pengaruh ROI, QR, TATO, PER Pada Harga Saham Perusahaan Batu Bara di BEI. Jurnal Ilmiah Ekonomi. Vol 3. No 1.

Tamba, Amelia Yurike., Parengkuan Tommy dan Paulina Van Rate. (2017). Analisis Pengaruh Struktur Modal Terhadap Profitabilitas pada Industri Perbankan yang Terdaftar di BEI (Periode Tahun 2013-2015). Jurnal EMBA. Vol 5. No 2.

Tahu, Gregorius Paulus \& Dominicius Djoko Budi Susilo. (2017). Effect of liquidity, leverage and profitability to the firm value (dividend policy as moderating variable) in manufacturing company of indonesia stock exchange. Research Journal of Finance and Accounting. Vol 8. No 18.

Tarima, Grandy., Tommy \& Victoria. (2016). Pengaruh Profitabilitas, Keputusan Investasi Dan Keputusan Pendanaan Terhadap Nilai Perusahaan Farmasi Yang Terdaftar di BEI Periode 2011-2014. Jurnal Berkala Ilmiah Efisiensi. Vol 16. No 4.

Taufiq, Rahmat dan Wahidahwati. (2016). Faktor-Faktor Yang Mempengaruhi Indeks Harga Saham Pada Perusahaan yang Terdaftar di Jakarta Islamic Index. Jurnal Ilmu dan Riset Akuntansi. Volume 5. Nomor 8.

Wang, B. (2018). Ownership, institutions and firm value: Cross-provincial evidence from China. Research in International Business and Finance, 44, 547-565.

Yumia, Martisa Nabila dan Khairunnisa. (2015). Pengaruh Return On Equity (ROE), Earning Per Share (PER) dan Price Earning Ratio (PER) terhadap Harga Saham (Studi Kasus pada Perusahaan Pertambangan Logam dan Mineral Periode 2010-2014). EProceding of Management. Vol 2. No 3.

Zeitun, Rami dan Ali Salman Saleh. (2015). Dynamic Performance, Financial Leverage and Financial Crisis: Evidence From GCC Countries. EuroMed Journal of Business, Vol. 10 Issue 2. pp.147-162. 